\title{
Neonatal Transient Hypothyroidism in Two Whippet Puppies
}

\author{
J. KOLEVSKÁ ${ }^{1}$, V. BRUNCLÍK ${ }^{1}$, L. BARTOŠOVÁ ${ }^{2}$ \\ ${ }^{1}$ Clinic for Dog and Cat Diseases, Faculty of Veterinary Medicine, University of Veterinary \\ and Pharmaceutical Sciences Brno \\ ${ }^{2}$ Department of Human Pharmacology and Toxicology, Faculty of Veterinary Medicine, \\ University of Veterinary and Pharmaceutical Sciences Brno, Czech Republic
}

Received June 23, 2006

Accepted January 4, 2007

\begin{abstract}
Kolevská J., V. Brunclík, L. Bartošová: Neonatal Transient Hypothyroidism in Two Whippet Puppies. Acta Vet. Brno 2007, 76: 277-282.

The work describes a case of neonatal transient hypothyroidism in two whippet puppies aged 10 weeks. The condition was caused by iodine deficiency either in the diet solely or in combination with a partial peroxidase defect. Goitre developed in the puppies, fed giblets and poultry meat. Laboratory examinations in both puppies showed symptoms of hypothyroidism: non-regenerative anaemia, hypercholesterolaemia, significant decrease in the concentration of total thyroxine and increased concentration of thyrotropin. Ultrasonographic examination demonstrated enlarged thyroid glands. Cytological examination confirmed hyperplastic epithelial cells of the thyroid gland. The clinical condition improved within two months after the diet was changed to commercial dog food and after oral iodine supplementation was started. The iodine substitution was gradually discontinued. Four years later, the clinical and laboratory examinations were carried out in one of the presented patients under completely different circumstances (examination after a car accident). Haematological, biochemical and hormonal examinations were entirely within the reference range.
\end{abstract}

Peroxidase defect, iodine deficiency, goitre, dog

Hypothyroidism is a disease with several different aetiologies and pathogeneses. Its only common feature is a lack of thyroid hormones (Němec and Zamrazil 1997). Hypothyroidism is one of the most common endocrinopathies in adult dogs, but its occurrence in puppies is described only rarely. In adults, $95 \%$ of cases are due to primary hypothyroidism. Secondary hypothyroidism occurs in less than $5 \%$ of cases (Feldman and Nelson 1996; Rijnberk 1996; Day 1999). Primary hypothyroidism (dysfunction at the level of the thyroid gland) is most frequently caused by autoimmune mechanisms (Happ 1995; Kolevská et al. 2002), and less frequently due to iatrogenic causes. Circulating autoantibodies against thyroglobulin are detected in more than $50 \%$ of dogs with hypothyroidism (Young et al. 1991; Gaschen et al. 1993). Secondary hypothyroidism (dysfunction at the level of the pituitary gland) occurs as a result of adenopituitary malformations (cyst, neoplasm), hypophysectomy or suppression of thyrotropic cells due to long-term corticosteroid therapy (Feldman and Nelson 1996; Ramsey et al. 1997; Kooistra et al. 1998).

Juvenile hypothyroidism occurs in congenital or acquired forms. The prevalence of congenital hypothyroidism is rare. Thyroid dysgenesis, including thyroid aplasia (agenesis), hypoplasia, and ectopy, is responsible for $80 \%$ of congenital hypothyroidism in man. The remaining $20 \%$ is caused by inborn errors in the thyroid gland. Hereditary defects at virtually all levels of thyroid hormone synthesis, secretion, and action have been identified (Niu et al. 2005). In the dog and cat the following forms of congenital hypothyroidism are known to occur: thyroid dysgenesis and defective thyroid hormone synthesis and action

\footnotetext{
Address for correspondence:

MVDr. Jana Kolevská, Ph.D.

Clinic for Dog and Cat Diseases

Faculty of Veterinary Medicine

University of Veterinary and Pharmaceutical Sciences

Palackého 1 - 3, 61242 Brno, Czech Republic
}

Phone: +420 541562363

E-mail: kolevskaj@email.cz

http://www.vfu.cz/acta-vet/actavet.htm 
(Eigenmann et al. 1981; Chastain 1983; Tanase et al. 1991; Fyfe et al. 2003). Thyroid peroxidase deficiency is most frequently caused by hereditary defects of thyroid hormone synthesis in humans as well as in dogs and cats (Sjollema et al. 1991; Fy fe et al. 2003; Niu et al. 2005).

Acquired thyroid disorders in juvenile animals are also rare. Occasionally it is possible to observe hypothyroidism due to iodine deficiency in the diet (Feldman and Nels on 1996). Another cause of acquired juvenile-onset hypothyroidism, although also very rare, is lymphocytic thyroiditis (Rijnberk 1996).

Early in life the presence of thyroid hormones is crucial for growth and development of all body tissues and particularly the skeleton. Hence in addition to the signs of adult-onset hypothyroidism, disproportionate dwarfism may be a prominent sign of congenital or juvenile-onset hypothyroidism. In case of defective synthesis of thyroid hormones the condition is manifested by goitre (Rijnberk 1996).

This paper describes neonatal transient hypothyroidism in two whippet puppies. The condition was clinically manifested by goitre and laboratory signs of primary hypothyroidism, and it was probably caused by dietary iodine deficiency. In these two puppies, partial defect of peroxidase and of goitrogens in prenatal and postnatal development was not proved, but it could have influenced the condition in combination with other factors.

\section{Case Description and Results}

Four ten-week-old whippet puppies were presented to the Small Animal Clinic of the Faculty of Veterinary Medicine, University of Veterinary and Pharmaceutical Sciences, Brno. The animals were presented for a regular examination and primary vaccination. Physical examination showed no disorders in two puppies out of four. Visual examination and palpation in the other two puppies revealed distinct bilateral swellings in the ventral area of the neck (Plate XIV, Figs 1 and 2, Plate XV, Fig 3). According to the history, the owner noticed no abnormalities until 10 days prior to the examination. The swellings reportedly increased in size over a period of approximately 14 days. Dietary history revealed that from five weeks of age the puppies were fed exclusively giblets and poultry meat. The bitch (the mother of the puppies) was fed the same diet.

Examination on the ventral neck revealed macroscopically visible swellings in the area of the first tracheal rings. Palpation confirmed two subcutaneous lobular swellings (each approximately $10 \mathrm{~cm}$ long, $4 \mathrm{~cm}$ wide and $3 \mathrm{~cm}$ deep). The swellings were firm, painless and fixed with regard to surrounding tissues. No other abnormalities were found during the physical examination.

Laboratory examination in both puppies confirmed non-regenerative anaemia. In one puppy the anaemia was clearly non-regenerative, in the other one the anaemia was on the borderline between regenerative and non-regenerative. Eosinophilia was found in the differential blood count in the second puppy. The results of several biochemical examinations showed borderline hypercholesterolaemia, mild hyperglycaemia (the puppies did not fast prior to the visit) and mild hypoproteinaemia appropriate to the age of the puppies. Haematological and biochemical values for both patients are shown in Table 1. Physical and chemical examinations of urine did not show any deviations from physiological standards. Parasitological examination of faeces revealed toxocariasis in all four puppies.

The following additional diagnostic examinations were carried out: radiography of the neck, ultrasonography of the swellings in the ventral regions of the neck and cytological examination of a fine needle aspirate from the swellings. Total thyroxine $\left(\mathrm{tT}_{4}\right)$ and thyrotropin (TSH) concentrations were determined in both puppies by means of 
Table 1. Haematological and biochemical values in the dogs presented for examination

\begin{tabular}{|c|c|c|}
\hline Parameter (unit) & Dog No. 1 & Dog No. 2 \\
\hline Haemoglobin $(\mathrm{g} / \mathrm{L})$ & 67 & 71 \\
\hline Haematocrit (1/L) & 0.19 & 0.18 \\
\hline Erythrocytes $\left(10^{12} / \mathrm{L}\right)$ & 2.79 & 3.65 \\
\hline Leukocytes $\left(10^{9} / \mathrm{L}\right)$ & 5.4 & 9.8 \\
\hline Metamyelocytes $\left(10^{9} / \mathrm{L}\right)$ & 0.108 & 0.784 \\
\hline Segmented cells $\left(10^{9} / \mathrm{L}\right)$ & 3.672 & 4.704 \\
\hline Lymphocytes $\left(10^{9} / \mathrm{L}\right)$ & 1.404 & 2.254 \\
\hline Monocytes $\left(10^{9} / \mathrm{L}\right)$ & 0.054 & 0 \\
\hline Eosinophils $\left(10^{9} / \mathrm{L}\right)$ & 0.162 & 2.058 \\
\hline Reticulocytes $\left(10^{9} / \mathrm{L}\right)$ & 22.32 & 64.05 \\
\hline Total protein $(\mathrm{g} / \mathrm{L})$ & 52.1 & 54.1 \\
\hline Albumin $(\mathrm{g} / \mathrm{L})$ & 29.2 & 29.8 \\
\hline Glucose $(\mathrm{mmol} / \mathrm{L})$ & 8.22 & 7.41 \\
\hline Creatinine $(\mu \mathrm{mol} / \mathrm{L})$ & 55.9 & 52.7 \\
\hline Urea (mmol/L) & 6.34 & 7.08 \\
\hline ALP (IU/L) & 116.471 & 134.706 \\
\hline ALT (IU/L) & 25.294 & 37.647 \\
\hline $\operatorname{AST}(\mathrm{IU} / \mathrm{L})$ & 28.235 & 28.235 \\
\hline Triglycerides $(\mathrm{mmol} / \mathrm{L})$ & 0.48 & 0.48 \\
\hline Cholesterol (mmol/L) & 7.16 & 7.25 \\
\hline Sodium $(\mathrm{mmol} / \mathrm{L})$ & 145 & 145 \\
\hline Calcium $(\mathrm{mmol} / \mathrm{L})$ & 2.89 & 3.11 \\
\hline Potassium $(\mathrm{mmol} / \mathrm{L})$ & 3.9 & 4.77 \\
\hline Phosphorus (mmol/L) & 2.26 & 2.67 \\
\hline tT4 (nmol/L) & 5.0 & 5.0 \\
\hline $\mathrm{cTSH}(\mathrm{ng} / \mathrm{mL})$ & 4.7 & 4.7 \\
\hline
\end{tabular}

ALP Alkaline phosphatase, ALT Alanine aminotranfserase,

AST Aspartate aminotransferase, tT4 Total thyroxine, cTSH Canine thyrotropin

(Copyright 2001, with permission of Veterinářství)

chemiluminescent immunoassay. A species-specific test with monoclonal antibodies against dog TSH (Immulite ${ }^{\circledR}$ canine TSH, DPC, Los Angeles, USA) was used for the analysis. Total thyroxine was determined by chemiluminescent enzymeimmunoassay (Immulite ${ }^{\circledR}$, Total $\mathrm{T}_{4}$, DPC, Los Angeles, USA). Hemacolor ${ }^{\circledR}$ (Merck, Darmstadt, Germany) staining was used for the aspiration specimen.

Radiography showed increased tissue density in the area of the swelling in the ventral region of the neck. Ultrasonography revealed homogeneously increased total volume of the thyroid gland (Plate XVI, Figs 5 and 6). Cytological examination of the thyroid fine needle aspirate specimen showed hyperplasia of epithelial cells of the thyroid gland (Plate XV, Fig. 4). Parallel comparison of total thyroxine and thyrotropin concentrations in serum showed that total thyroxine concentrations were significantly reduced to under the minimum limit of detection of the method $(5.0 \mathrm{nmol} / \mathrm{l})$, while cTSH concentrations were significantly increased $(4.7 \mathrm{ng} / \mathrm{ml})$. The final diagnosis was primary hypothyroidism.

Two alternatives were considered for differential diagnosis: (1) goitre due to iodine deficiency in the diet (more likely with regard to the data from history); or (2) a peroxidase defect leading to defective synthesis of the thyroid hormone (a very rare condition).

Based on the history of an inadequate diet, and since scintigraphy was not available to rule out a peroxidase defect, we commenced substitution therapy with iodine (Jodid 100 tbl., Merck at the total dose of $100 \mu \mathrm{g}$ per day divided into two doses for each day of 
treatment).We also recommended that the owner change the diet to commercial dog food. Since toxocariasis was also found in the puppies, they were repeatedly dewormed with pyrantel (Banminth paste ad us. vet.; Pfizer). After two months of treatment the goitre disappeared, and the patients showed no signs of hypothyroidism on physical examination. Within the following two months iodine substitution was gradually discontinued and it was suggested that the owner continue feeding the dogs commercial dog food and avoid giblets. The owner did not appear for any other check up. Four years later, the clinical and laboratory examinations were carried out in one of the presented patients under completely different circumstances (examination after a car accident). Clinical examination showed no abnormalities. Haematological, biochemical and hormonal examinations were entirely within the reference range ( $\mathrm{tT}_{4} 32 \mathrm{nmol} / \mathrm{l}$ and $\mathrm{cTSH} 0.2 \mathrm{ng} / \mathrm{ml}$ ).

\section{Discussion}

Juvenile hypothyroidism is a relatively rare disease in dogs, although its exact incidence is not known. Feldman and Nelson (1996) reported that congenital hypothyroidism accounted for only $3.6 \%$ of all forms of hypothyroidism. However, the same authors expected that the real number would be somewhat higher in practice, because many patients die shortly after birth, they are not referred to specialists or fall within the category of the fading puppy syndrome (Feldman and Nels on 1996). The diagnosis of acquired juvenile hypothyroidism is also rare.

Although in human medicine much attention is paid to hypothyroidism resulting from iodine deficiency, in veterinary medicine the same condition is less commonly recognised. This is most probably due to the fact that, because of different renal clearance rates compared to humans, the dog requires a smaller exogenous intake of iodine. In addition, most dogs are completely or partially fed with commercial dog food, where iodine is available in sufficient quantities (Feldman and Nelson 1996; Rijnberk 1996). In humans, the values for average recommended iodine intake vary between 150 and $200 \mu \mathrm{g}$ per person per day (Zamrazil 1999). However, in the dog the daily requirements reported by various sources are rather different. The recommended daily dose of iodine is usually reported to be around $140 \mu \mathrm{g}$ per animal per day (Feldman and Nels on 1996). However, the same authors reported that no clinically apparent goitre developed in beagles even after the administration of iodine doses as low as $20 \mu \mathrm{g}$ per animal per day. Goitre may develop in exceptional cases when the dog is fed a diet consisting exclusively of meat and viscera. Such diets contain insufficient quantities of iodine (Rijnberk 1996). It is unknown, if toxocariasis can increase required amount of iodine intake. Due to iodine deficiency thyroxine synthesis is essentially blocked. Lack of thyroxine causes increased TSH secretion. TSH stimulation results in hyperplasia of the thyroid tissue, which is clinically manifested by goitre. In cases of slight iodine deficiency, pituitary stimulation leads to a compensatory increase in thyroxine secretion, and the animal remains clinically euthyroid. More serious cases of significant iodine deficiency are manifested as hypothyroidism (Rijnberk 1996).

The diagnosis of iodine deficiency in human medicine can be confirmed by the analysis of food consumed, determination of iodine in urine, and determination of the volume of the thyroid glands. However, iodine analysis in food is difficult, and even in human medicine it is only performed in targeted studies. Exact reference ranges exist in human medicine for the assessment of iodine concentration in urine and thyroid gland volume (Za mrazil 1999; Kolevská and Kohout 2001). A goitre confirmed by palpation is clinically important but is not diagnostically specific. It is also possible to use TSH determination to aid in the diagnosis of iodine deficiency. However, in case of euthyroid animals no deviations from normal values will be found. As there are no reference values in veterinary medicine for the evaluation of iodine content in urine, we did not carry out this analysis. 
The aetiological confirmation of iodine deficiency in our patients was based on the following criteria: goitre, typical clinical and laboratory symptoms of primary hypothyroidism (non-regenerative anaemia, hypercholesterolaemia, significantly reduced concentration of total thyroxine, significantly increased TSH concentration), ultrasonographic findings, cytological examination of a fine needle aspiration specimen of the thyroid tissue, and response to therapy.

Besides the iodine deficiency, we also considered the possibility of a peroxidase defect. Peroxidase is an enzyme which is necessary for the animal to utilise iodide for thyroxine synthesis ( Sjollema et al. 1991). Peroxidase defects may be total or partial. In some cases just a change in enzyme location may take place. Under normal conditions peroxidase is located in follicular cells of the thyroid gland (Jones et al. 1992). Besides the permanent form of congenital hypothyroidism induced by peroxidase defects, neonatal transient hypothyroidism (NTH) has often been detected in humans. The causes remain incompletely understood. Environmental factors (including iodine deficiency), maternal factors (such as intrauterine exposure to antithyroid drugs, iodine, or maternal antithyroid antibodies, and neonatal factors (prematurity) have all been associated with NTH. The carriers of thyroid peroxidase gene defects may be susceptible to the development of NTH during the stress and other environmental factors such as iodine deficiency ( $\mathrm{Niu}$ et al. 2005).

The diagnosis of a peroxidase defect is confirmed by measuring changes in the radioactivity (via scintigraphy) of thyroid tissue after the administration of radioactive iodine together with another competitive radionuclide at specific time intervals ( $\mathrm{Nap}$ et al. 1994). We did not carry out this examination because the availability of scintigraphy for veterinary purposes is very limited. The aetiologies of the goitre in our patients were instead confirmed by a therapeutic trial. Clinical signs disappeared two months after the start of the therapy, which consisted of a change in diet (to commercial food) and oral iodine substitution. This therapeutic result enabled us to rule out a total peroxidase defect. If the condition had been a total peroxidase defect (or a defect due to a lack of the thyroid gland reaction to $\mathrm{TSH}$, or rarely occurring juvenile autoimmune lymphocytic thyroiditis), iodine supplementation would not have led to improvement in the condition. In such cases, only thyroxine therapy would have led to the effect. With respect to the fact that similar clinical and laboratory problems were absent in two other puppies from the same litter and the bitch (the mother of the puppies), though they were fed the same diet (giblets and poultry meat), we cannot entirely rule out the possibility that the two affected puppies suffered from a partial peroxidase defect. Partial peroxidase defect combined with other factors (iodine deficiency in diet, the effect of goitrogens) could then account for the fact that the primary hypothyroidism displayed certain clinical and laboratory signs only in the two individuals from the litter.

\section{Juvenilní hypotyreóza u dvou štěňat whippetů}

Práce popisuje případ přechodné neonatální hypotyreózy u dvou 10 týdenních štěňat whippetů, který byl vyvolán deficitem jodu v krmné dávce samostatně nebo v kombinaci s částečným peroxidázovým defektem. K rozvoji strumy došlo u dvou štěňat whippetů krmených výhradně drůbežím masem a drůbežími vnitřnostmi. Laboratorně vykazovala obě štěňata příznaky hypotyreózy: neregenerativní anémii, hypercholesterolémii, signifikantně sníženou koncentraci celkového tyroxinu a signifikantně zvýšenou koncentraci thyreotropinu. Ultrasonografické vyšetření prokázalo zvětšení štítné žlázy. Cytologicky se prokázala hyperplazie epiteliálních buněk štítné žlázy. Dva měsíce po změně krmné dávky a zahájení perorální substituce jodem došlo k vymizení klinických příznaků. Substituce jodem byla postupně ukončena. Čtyři roky po skončení terapie bylo u jednoho z pacientů provedeno klinické a laboratorní vyšetření ve zcela jiné souvislosti (vyšetření po úraze 
autem). Hematologické, biochemické i hormonální vyšetření se pohybovalo v rámci referenčního rozmezí.

\section{Acknowledgement}

The authors wish to thank MVDr. Pavel Kohout, Ph.D. for ultrasonographic and cytological examination of the patients.

\section{References}

CHASTAIN CB 1983: Congenital hypothyroidism in a dog due to an iodide organification defect. Am J Vet Res 44: $1257-1258$

DAY MJ, SHAW SE 1999: Canine hypothyroidism. In: DAY MJ: Clinical immunology of the dog and cat. Manson Publishing, London, pp. 162-166

EIGENMANN JE 1981: Diagnosis and treatment of dwarfism in a German Shepherd dog. J Am Anim Hosp Assoc 17: $198-200$

FELDMAN EC, NELSON RW 1996: Canine hypothyroidism. In: FELDMAN EC, NELSON RW (Eds): Canine and Feline Endocrinology and Reproduction, $2^{\text {nd }}$ edition. W. B. Saunders, Philadelphia. pp. 70- 115

FYFE JC, KAMPSCHMIDT K, DANG V, POTEET BA, HE Q, LOWRIE C, GRAHAM PA, FETRO VM 2003 : Congenital hypothyroidism with goiter in toy foxterriers. J Vet Intern Med 17: 1-57

GASCHEN F, THOMPSON J, BEALE K, KEISLING K 1993: Recognition of triiodothyronine-containing epitopes in canine thyroglobulin autoantibodies. Am J Vet Res 54: 244-247

HAPP GM 1995: Thyroiditis - a model canine autoimmune disease. Adv Vet Sci Comp Med 39: 97-139

JONES BR, GRUFFYDD-JONES TJ, SPARKES AH, LUCKE VM 1992: Preliminary studies on congenital hypothyroidism in a family of Abyssinian cats. Vet Rec 131: 145-148

KOLEVSKÁ J, KOHOUT P 2001: Juvenilní hypotyreóza u dvou štěňat vipetů. Veterinářství 51: 308-310

KOLEVSKÁ J, SVOBODA M, BRUNCLÍK V 2002: Parallel Determination of Total Thyroxine and Thyrotropin Concentrations in Diagnosis of Primary Hypothyroidism in the Dog. Acta Vet Brno 71: 61-67

KOOISTRA HS, VOORHOUT G, SELMAN PJ, RIJNBERK A 1998: Progestin-induced growth hormone (GH) production in the treatment of dogs with congenital GH deficiency. Domest Anim Endocrinol 15: 93 - 102

NAP AMP, POLLAK YWEA, VAN DEN BROM WE, RIJNBERK A 1994: Quantitative aspects of thyroid

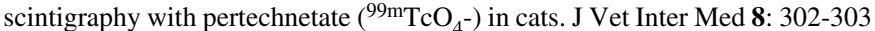

NĚMEC J, ZAMRAZIL V 1997: Štítná žláza. In: STÁRKA L: Endokrinologie. Maxdorf, Praha, pp. 77-97

NIU DM, LIN CY, HWANG B, JAP TS, LIAO CJ, WU JY 2005: Contribution of genetic factors to neonatal transient hypothyroidism. Arch Dis Child-Fetal Neonatal Ed 90: 69-72

RAMSEY IK, EVANS H, HERRTAGE ME 1997: Thyroid-stimulating hormone and total tyroxine concentrations in euthyroid, sick euthyroid and hypothyroid dogs. J Small Anim Pract 38: 540-545

RIJNBERK A 1996: Hypothyroidism in young animals. In: RIJNBERK A: Clinical endocrinology of dogs and cats. Kluwer Academic Publishers, Dordrecht, pp. 38-42

SJOLLEMA BE, DEN HARTOG MT, DE VIJLDER JJM, VAN DIJK JE, RIJNBERK A 1991: Congenital hypothyroidism in two cats due to defective organification: data suggesting loosely anchored thyroperoxidase. Acta Endocrinol 125: 435-440

SVOBODA M, DOUBEK J, ČADA F 1998: Hypotyreóza. In: SVOBODA M, DOUBEK J: Endokrinologie psa a kočky. ČAVLMZ, Brno, pp. 159-169

TANASE H, KUDO K, HORIKOSHI H, MIZUSHIMA H, OKAZAKI T, OGATA E 1991: Inherited primary hypothyroidism with thyrotrophin resistance in Japanese cats. J Endocrinol 129: 45-251

YOUNG DW, HAINES DM, KEMPPAINEN RJ 1991: The relationship between autoantibodies to triiodothyronine $\left(\mathrm{T}_{3}\right)$ and thyroglobulin $(\mathrm{Tg})$ in the dog. Autoimmunity 9: 41-46

ZAMRAZIL V 1999: Jodový deficit, jeho význam a způsoby řešení. In: STÁRKA L: Aktuální endokrinologie. Maxdorf, Praha, pp. 366- 391 
Plate XIV

Kolevská J. et al.: Neonatal Transient ... pp. 277-282

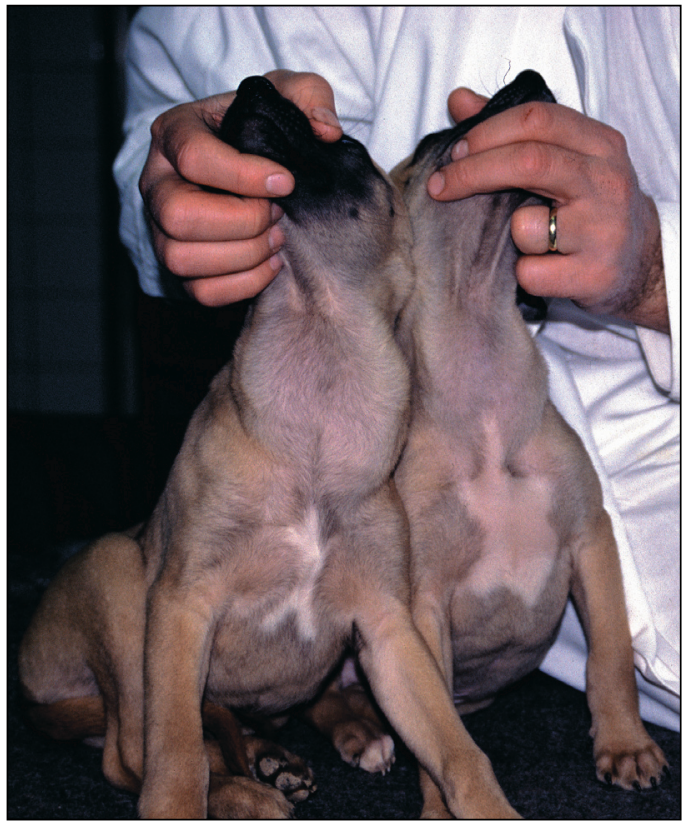

Fig. 1. Goitre in the two affected whippet puppy (Copyright 2001, with permission of Veterináŕství)

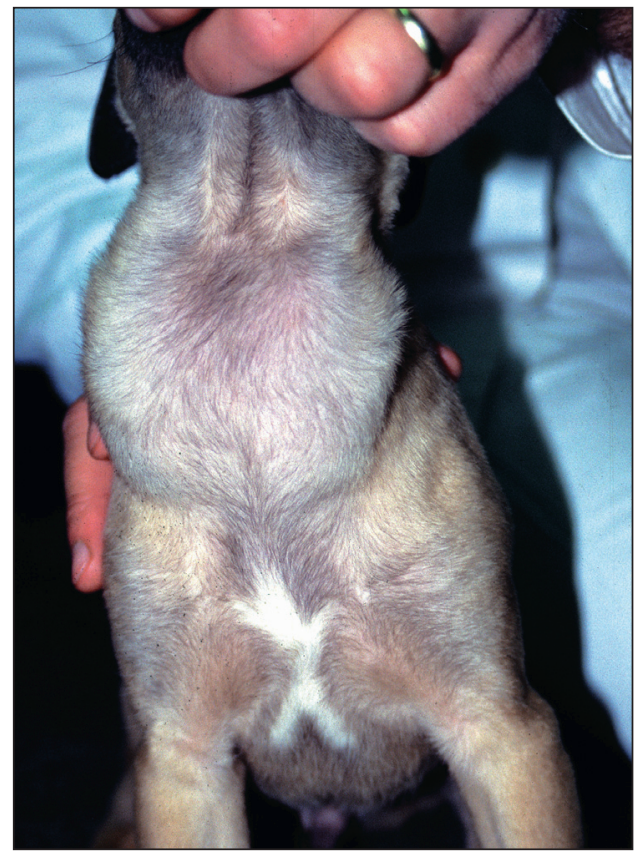

Fig. 2. Detailed picture of the goitre (Copyright 2001, with permission of Veterinářství) 


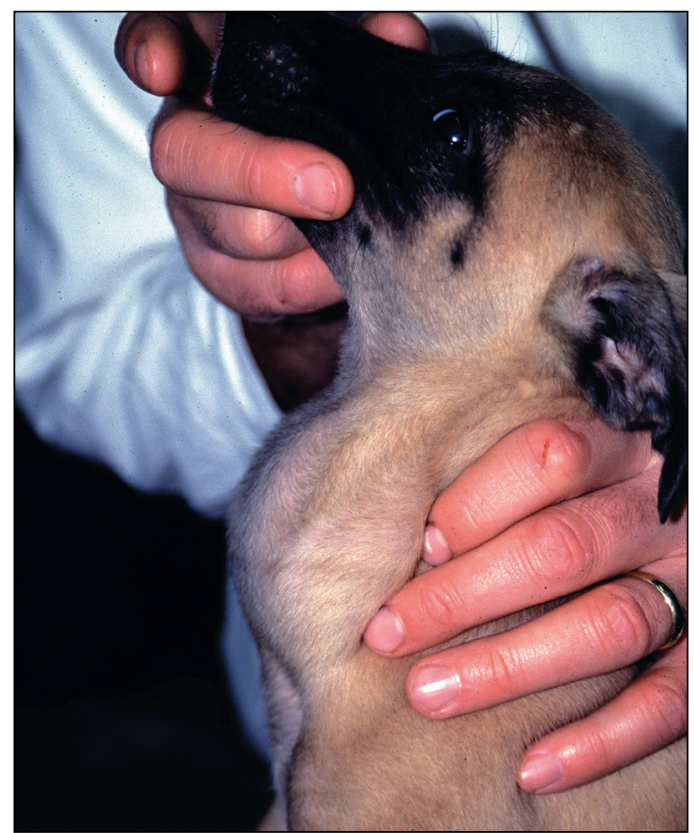

Fig. 3. Detailed picture of the goitre

(Copyright 2001, with permission of Veterinářství)

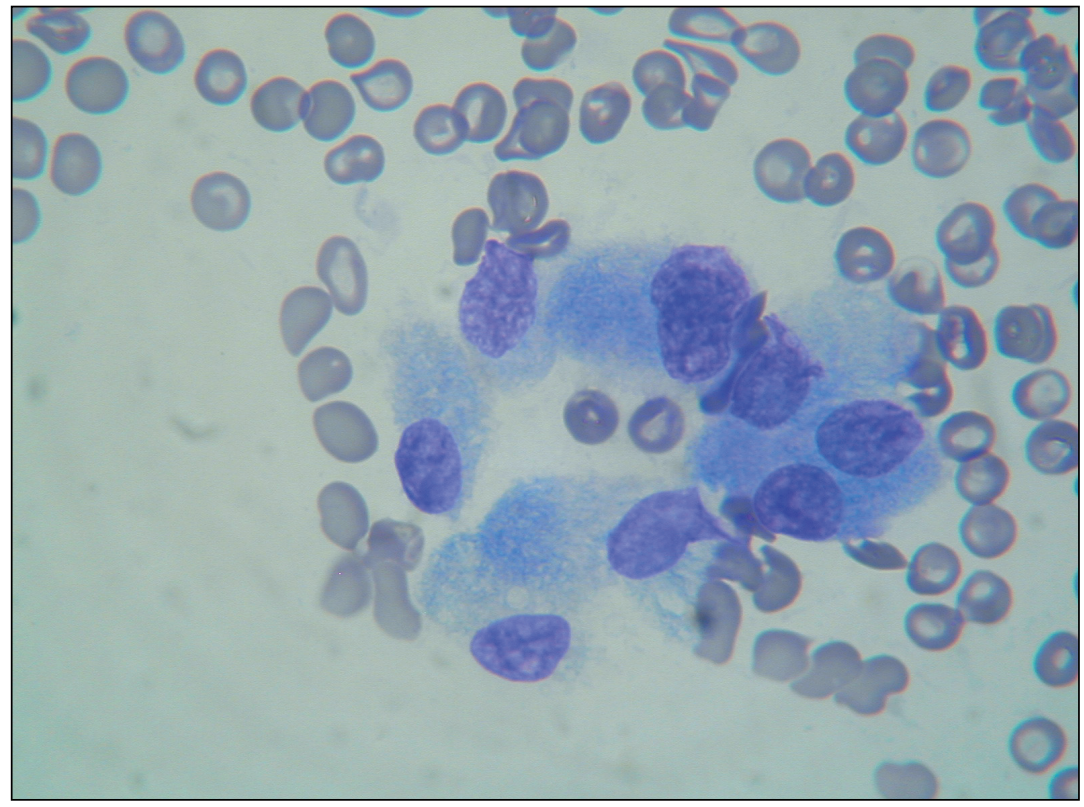

Fig. 4. Cytological examination of the fine needle aspirate specimen of the thyroid tissue Hyperplasia of thyroid epithelial cells. The cells have increased nucleo-cytoplasmic ratio. The differences in the size of the cells and the nuclei between cells is minimal. Nuclear chromatin has a fine granular structure and the cytoplasm is light blue. Nucleoli are not clearly visible. Hemacolor x 1250 (Copyright 2001, with permission of Veterinářství) 


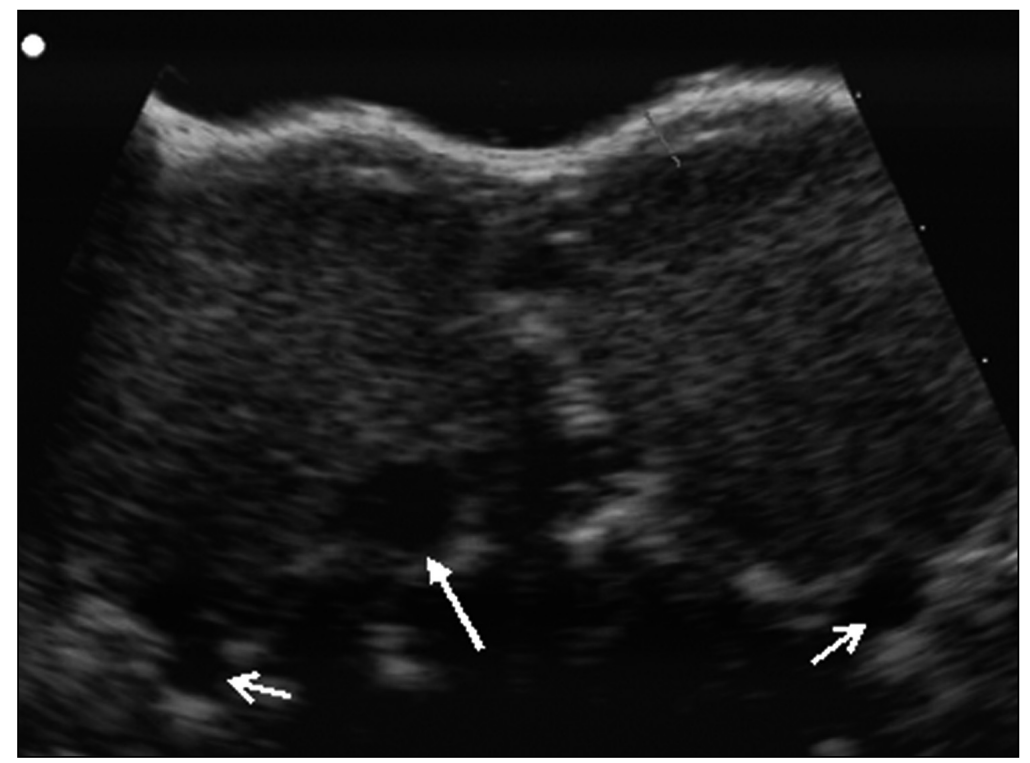

Fig. 5. Ultrasonography - transverse section through the ventral area of the neck. The right and the left lobes of the thyroid gland are symmetrically enlarged. The tissue shows moderate echogenicity. The right lobe contains an anechogenic cyst of $8 \mathrm{~mm}$ diameter (solid white arrow). Empty white arrows indicate carotis artery on the left and right sides (Copyright 2001, with permission of Veterinářství)

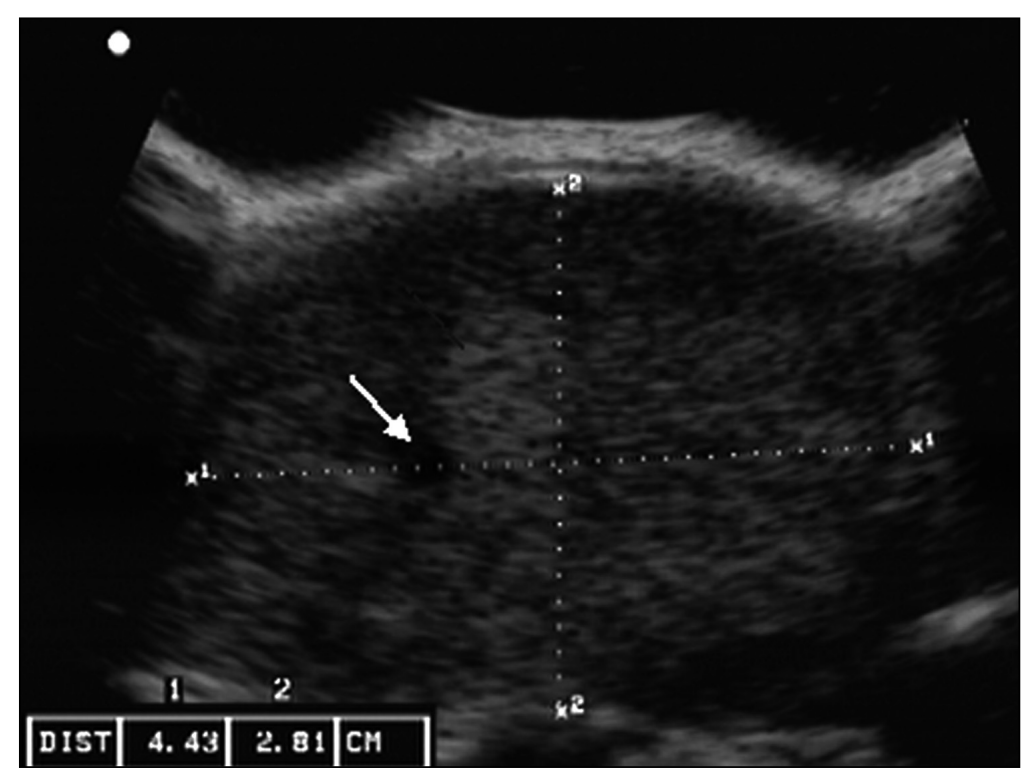

Fig. 6. Ultrasonography - longitudinal section through the ventral area of the neck. The left lobe of the thyroid gland is enlarged $(4.43 \times 2.81)$. The normal thyroid gland in a medium sized dog is about 2.5 to $3.0 \mathrm{~cm}$ long and 0.4 to $0.6 \mathrm{~cm}$ wide. The solid white arrow indicates an anechogenic cystic lesion

(Copyright 2001, with permission of Veterinářství) 